\title{
Exploration and Practice Reform on Power System Analysis
}

\author{
Sun Qiang ${ }^{\mathrm{a}}$, Zhang Weiyu ${ }^{\mathrm{b}}$, Du Yanhong ${ }^{\mathrm{c}}$, Li Jin $^{\mathrm{d}}$ \\ College of Engineering and Technology \\ Tianjin Agricultural University \\ Tianjin, China \\ a sunqiang@tjau.edu.cn; ${ }^{b}$ zhangweiyu@tjau.edu.cn; \\ cyanhong_du@163.com; ${ }^{\mathrm{d}}$ 503581900@qq.com
}

\author{
Wang Shasha \\ Beijing Electric Vehicle Co., Ltd. \\ Beijing, China \\ wangshasha@bjev.com.cn
}

\begin{abstract}
Power system analysis is a basis course for the persons majoring electrical engineering. The course design is a combination of power system analysis of the theoretical teaching, practical courses. The goal of the local university is cultivating applied technology talents, relying on the bridge role of cooperation between universities and enterprises in practical teaching, with the development of higher education, the course are facing the problem of more contents to teach and less class time given. Combining with the practical experience, the paper presents reformative teaching method in the following aspects: to regulate and optimize the teaching contents, to improve the didactical methods, to mobilize the activity of the students, to emphasize on the basic theories and practical training. This paper notes reform measures through the analysis of the current practical teaching of power system analysis, which has laid a well foundation to realize the transformation of university development trend, and the method is verified effectively in practice.
\end{abstract}

Keywords-power system analysis; innovation and practice; reform

\section{INTRODUCTION}

Reform of power system analysis course and the research of related problems has become a rising concern between teachers related to in colleges and universities or vocational education researchers. While facing the many years of teaching reform, there are the teachers of researching the summary and analysis of the current status and teaching reform researchers combined with relevant theory to explore development trend of the future. Power system analysis in colleges and universities teaching reform and innovation, always have some practical method, in order to improve the quality in teaching, promote the development of teaching research, training teachers' favorable teaching responsibility, causes the student to have teacher resources better, learning environment better.

The main task of the course power system analysis is in order that the students master the basic theoretical knowledge about electronics and electrical, and learn the basic analysis method through the course. At the same time, through various methods to understand the electronic technology and new knowledge and new technology in the field of electrical engineering, to lay a solid foundation for the future

Undergraduate Teaching Quality and Teaching Reform Project of Colleges and Universities in Tianjin (171006107C); Innovation and Entrepreneurship Training Reform Model Projects of Tianjin Agricultural University (20170812, 20170102). professional learning[1]. So, in the teaching process, teachers should strengthen the basic knowledge of transmission, students only lay a solid theoretical foundation, can only be applied to practice. According to the electricity class specialized talent training scheme, two-thirds of the power system theory teaching occupies the whole class, and therefore to deepen the students' theoretical knowledge understanding, teachers' teaching is a systematic theory, make the student has a solid theoretical foundation for knowledge.

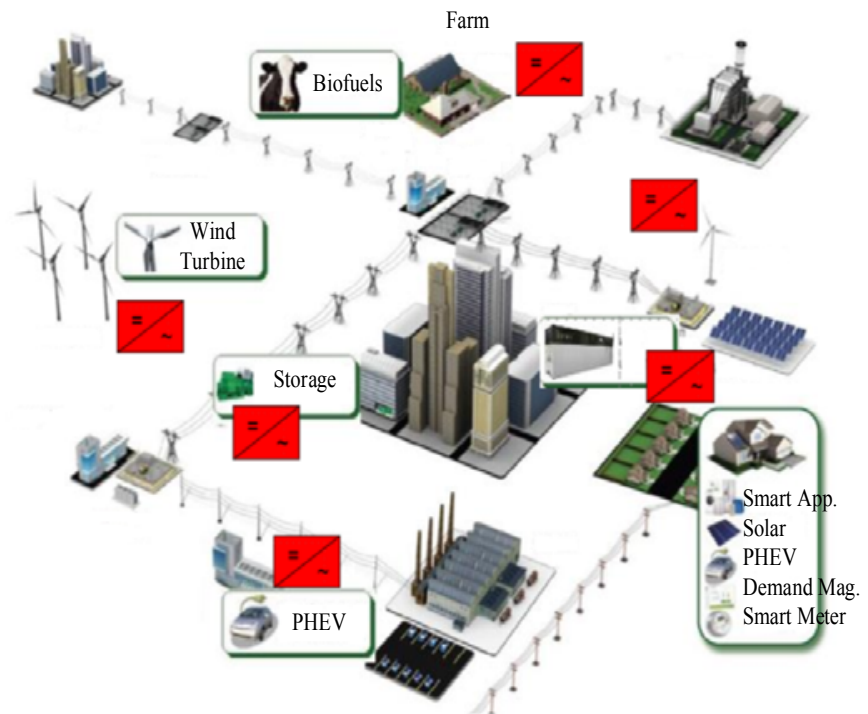

(a) Typical power system application field 


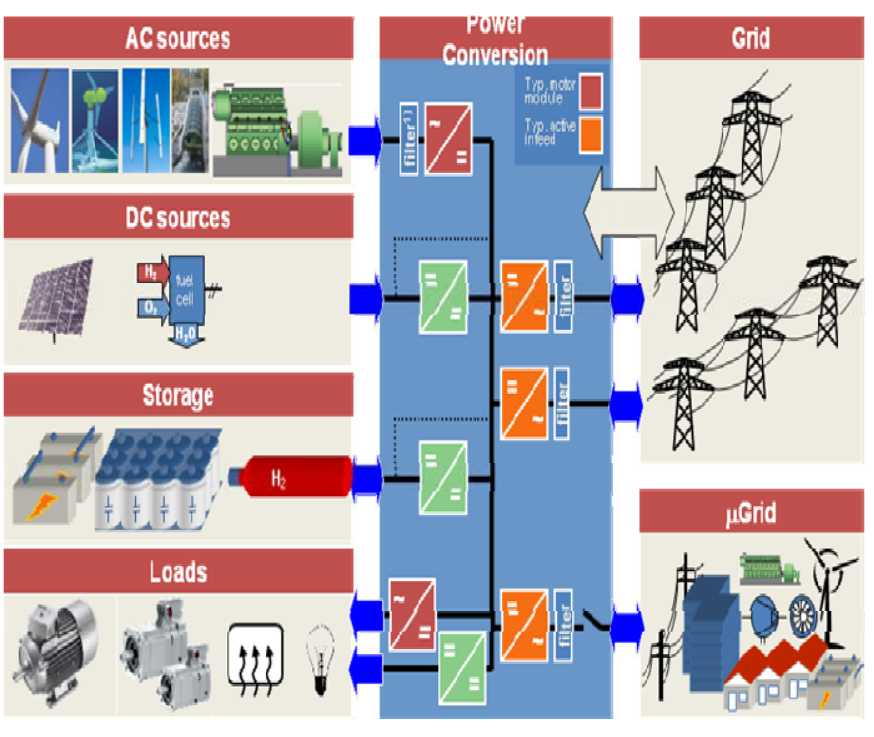

(b) General framework of energy interaction system

Fig. 1. Power system concepts and its further exploration based on power conversion technology.

Teacher's personal charisma has certain influence to the students. Teachers of power in colleges and universities should improve their own quality in teaching process. Teachers render students own to the charm of you, release the student to the academic vitality, and guide students to the electric field of knowledge. Teachers should set up good teaching consciousness, and set a good example, bring students into the world of electric power, students are encouraged to bold suspicion, design good teaching plan, adhere to the combination of theory and practice, strengthen practice class, to enlarge the platform of practice, let the students interests in power system[2]. In addition, the knowledge of other subjects effectively applied in power system, can also be very good to let the students understand the knowledge of electric power. Good teaching management pattern, can give students a better learning state, integration with other subjects about the lives of the power system. Improving the curriculum and teaching management make the analysis ability of students more and stronger.

\section{POWER SYSTEM TEACHING REFORM FROM THE VIEWPOINT OF TEACHING MEANS}

With the development of information technology, means of teaching has become diversified. Such as electronic whiteboard, computer, slides. These have become an important means of modern teaching, such as the Internet, it offers the potential for power system teaching method reform. For example, teachers use PowerPoint presentation definition, theory, shows the derivation process of the concrete with blackboard writing. It can effectively reduce the blackboard writing time, improve the classroom teaching efficiency; Use of the electronic whiteboard, teachers can direct to show the data to the student to carry on the preparation before class, and easy to mistake for students directly introduce students with examples, the classroom teaching process completely with the teaching process is given priority to, greatly reduce the class in preparation such as unnecessary time. Teachers use the Internet, the teaching content can be prepared directly implement relevant exercises to share, so that the students can be targeted training after class[3]. For video, teachers can also use the classroom teaching process in confusion arising from the application process for students to provide solutions, teachers can be "for class" model to the classroom, make power system teaching breakthrough the limitation of time region, as far as possible to meet university students in the process of learning and application to the needs of the knowledge of power system, with the deepening of information technology, the teaching method will continue to innovation.

For example, when teaching power system structure, first of all, teachers should show the specific electrical equipment with pictures to students, make students have an intuitive acquaintance with the electrical components of the power system[4]. When geographical wiring diagram and electrical wiring diagram of the system is given, the student will be wiring diagram of the electrical components of symbols and corresponds to the actual equipment, thus the abstract wiring diagram of the system with the actual system structure.

In the interpretation of the working principle of generator speed control system, if using blackboard writing for teaching, first of all, its structure is complex, need a certain class time onto the blackboard; secondly, because of the complexity degree of the working principle, explaining abstract by using blackboard, students are not easy to understand; Using multimedia teaching after we use animation to demonstrate its working process, saves time drawing on the blackboard, and can make the working process of the specific, intuitive, easy to understand. In a word, using multimedia courseware with blackboard writing teaching, not only increased the classroom information, but also broaden the student's field of vision, make the teaching form more vivid, enhance the teaching effect.

\section{THE REFORM OF THE TEACHING CONTENT}

Power system is a professional basic course, because the teaching objects are electrical major, the teaching content is consistent with the follow-up study of specialized courses, In order to grasp the basic concept, reduce mathematical reasoning, the interpretation of knowledge applied skills for teaching mainly[5]. Teaching should fully combine the professional characteristics of electrical disciplines, targeted to increase the students' professional knowledge, lay the foundation for the subsequent study.

For the electrical professional students, teaching class of electricity is less, is based on the principle of good enough and usefully, introduces the basic concept and principle of electric power system and the main analysis method, for some tedious mathematical formula derivation can avoid the inevitable, to prevent the student to have the fear to the power to learn. Such as interpretation of sinusoidal alternating circuit, its content is mainly to solve the circuit analysis method, the solving method and the process is the same as the DC, so this part can be dismissing with a few cursory. 
At the same time, with the continuous development of science and technology, power system have produced new knowledge[6], so the teaching content should be increase the power to learn some cutting-edge knowledge and emerging technologies, Get rid of the theory of practical knowledge which is original and divorced from reality. Teachers in the teaching process timely introduction of these advanced content, expand students' knowledge.

\section{REFORMATION OF PRACTICE TEACHING}

In the process of power system teaching, the students are lack the ability of autonomous learning. In order to achieve the "student-centered" teaching methods, students encounter problems, teachers set; let the students talk about their own views, to explore to find out the answer to the question. In this process, students will think independently and find out the answer to the question, by passive recipients into explorers of active study and solve problems, thus cultivating students' ability of thinking, and improve students' ability to actively explore problems.

Power has strong practicality; teachers teach theoretical knowledge and also train the students' ability to solve the problem. Usually students in understanding the theoretical knowledge, applied to the real life, in order to improve their ability. Therefore, the teacher in the process of teaching course should use more instances in life, to cultivate the students' learning desire and ability to think independently, learn to analyze the problem by them, and find the solution.

TABLE I. EXPERIMENTAL DESIGN OF POWER SYSTEM ANALYSIS

\begin{tabular}{|l|l|l|}
\hline \multicolumn{1}{|c|}{$\begin{array}{c}\text { Experimental } \\
\text { type }\end{array}$} & \multicolumn{1}{|c|}{$\begin{array}{c}\text { Experimental } \\
\text { name }\end{array}$} & \multicolumn{1}{|c|}{$\begin{array}{c}\text { Experimental content } \\
\text { \& requirement }\end{array}$} \\
\hline \multirow{5}{*}{$\begin{array}{l}\text { Simulation } \\
\text { Experiment }\end{array}$} & $\begin{array}{l}\text { Steady state } \\
\text { analysis and } \\
\text { modeling }\end{array}$ & $\begin{array}{l}\text { Steady state modeling } \\
\text { and PSASP data }\end{array}$ \\
\cline { 2 - 3 } & $\begin{array}{l}\text { Power flow } \\
\text { calculation }\end{array}$ & $\begin{array}{l}\text { Complex power flow } \\
\text { calculation with PSASP }\end{array}$ \\
\cline { 2 - 3 } & $\begin{array}{l}\text { Fault analysis and } \\
\text { modeling }\end{array}$ & Modeling with PSASP \\
\cline { 2 - 3 } & $\begin{array}{l}\text { Fault analysis } \\
\text { simulation }\end{array}$ & $\begin{array}{l}\text { Fault analysis with } \\
\text { computer }\end{array}$ \\
\cline { 2 - 3 } & $\begin{array}{l}\text { Stability analysis of } \\
\text { small disturbance }\end{array}$ & $\begin{array}{l}\text { Static state stability } \\
\text { phenomenon and } \\
\text { analysis method }\end{array}$ \\
\cline { 2 - 3 } & $\begin{array}{l}\text { Electro-magnetic \& } \\
\text { Electro-mechanical } \\
\text { transient stability } \\
\text { analysis }\end{array}$ & $\begin{array}{l}\text { Transient state stability } \\
\text { phenomenon and } \\
\text { analysis method }\end{array}$ \\
\cline { 2 - 3 } & $\begin{array}{l}\text { Static state safety } \\
\text { analysis }\end{array}$ & $\begin{array}{l}\text { Static state safety } \\
\text { analysis method of } \\
\text { power system }\end{array}$ \\
\hline
\end{tabular}

\section{A. Reform of Experiment Teaching Content}

At present, the electro-technics experiment course content and form are fixed, the emphasis of the lack of professional knowledge, it is against the purpose of the experiment teaching, also not conducive to the improvement of the student beginning ability. So, for some to streamline the verification experiment, to appropriately increase the complexity of the experiment, and the theory of knowledge, knowledge to a comprehensive display of electro-technics[7]. For example, in the circuit design of experiments, lets the student independently experiment scheme design, circuit design, and installation and debugging of the circuit, such as process, cultivate the students' learning autonomy.

\section{B. Reform the Experiment Teaching Way of Teaching}

Experiment teaching and theory teaching with equal status, so in the teaching process students are required to strictly abide by the experimental requirements, according to the experiment rules to complete the experiment, make students form a scientific learning attitude continuously, the construction of good experimental learning ethos[8]. In addition, the laboratory opening management is the key of the laboratory teaching, electrician laboratory shall be open to students with regularly, and when students have a need to design experiments, students can apply for timely arrangement through experimental study.

\section{Strengthen the Laboratory Construction}

With the continuous development of electric power and electronic technology, the teaching content, and experiment content was updated constantly, laboratory equipment and apparatus of the school also needs to be updated in a timely manner. Schools should increase investment in reform of the laboratory, implement comprehensive, open teaching mode, which satisfies the requirement of students' learning and practice constantly, lets the student can have access to in school close to jobs in the future work environment, once stepping into the society, to achieve docking[9].

\section{CONCLUSION}

In conclusion, in teaching practice of colleges and universities, through the research of teaching course reform method of the 'power system analysis', which makes the teaching break through the traditional single classroom blackboard writing teaching model, by the multimedia with blackboard writing classroom teaching methods, increasing network auxiliary teaching[10,11]. Set up scientific practice teaching system, through comprehensive experiment link to consolidate and deepen the students understanding of the power system related theory knowledge, can make students to the basic theory with engineering practice, so as to stimulate students' innovation ability, become a comprehensive thinking ability and comprehensive ability to deal with the problem of innovation and technology talents, this also is the purpose of our applied undergraduate education.

\section{ACKNOWLEDGMENT}

This work was financially supported by the Undergraduate Teaching Quality and Teaching Reform Project of Colleges and Universities in Tianjin (171006107C) and the Innovation and Entrepreneurship Training Reform Model Projects of Tianjin Agricultural University (20170812, 20170102). 


\section{REFERENCES}

[1] G. Yang, "Thought on Experimental Teaching Reform in Higher School in New Position," Research in Teaching, 2005, pp. 34-40.

[2] J. F. Xu, "An integrated-skills approach to the teaching of intensive reading: An empirical study of College English teaching reform," Foreign Language Teaching \& Research, 2002, pp. 21-26.

[3] J. S Cao, L. Xue, L. P. Jiang, X. D. Jiao, and J. R. Yu, "The Teaching Reform of Single Chip Microcomputer and Laboratory Construction," Research \& Exploration in Laboratory, 2005, pp. 181-185.

[4] R. L. Zhao, M. A. Ming, J. H. Peng, "Training Studens' Creative Ability through Experimental Teaching Reform," Laboratory Research \& Exploration, 2001, pp. 59-65.

[5] X. M. Huang, S. R. Zeng, K. Ye, CJ Zheng and Y. S. Wang, "Teaching Reform of Open Lab and Cultivation of Creative Personnel," Experimental Technology \& Management, 2006, pp. 11-16.

[6] Y. Song, "Exploration and Practice of Teaching Reform on the Basis of Design-oriented Integrative Experiment," Researches in Medical Education, 2007, pp. 48-53.
[7] J. Cheng, "Physical Education Teaching Reform under Credit System in Colleges and Universities," Journal of Beijing University of Physical Education, 2002, pp. 27-34.

[8] J. Kang, "The training of innovative talents and practice teaching reform in universities," Experimental Technology \& Management, 2009, pp. 41-47.

[9] Y. X. Feng, Z. H. Xu, "Exploration to the Teaching Reform of Engineering Mechanics Experiment," Research \& Exploration in Laboratory, 2004, pp. 60-67.

[10] J. Zhang, X. Niu, Z. Y. Zhang, and Z. K. Li, "Exploration and Practice of Comprehensive Experimental Teaching Reform," Research \& Exploration in Laboratory, 2007, pp. 21-25.

[11] M. Venkatasubramanian, K. Tomsovic, "Power System Analysis," Electrical Engineering Handbook, 2005, 23(89), pp. 761-778. 